\title{
The ear development time and yield of soft winter wheat in the forest steppe of the Middle Volga Region
}

\author{
Nadezhda Zakharova* and Nikolai Zakharov \\ P.A. Stolypin Ulyanovsk State Agrarian University, 432017 Ulyanovsk, Russia
}

\begin{abstract}
The duration of the growing season is an important, adaptively significant indicator for any crop variety. In wheat breeding, a reliable criterion for determining the maturity group of a variety is the ear formation period. The purpose of the study was to determine the ear formation period of soft winter wheat varieties of various ecological and geographical origins in the conditions of the forest steppe of the Middle Volga region, and also to determine its effect on yield. Among the studied varieties of wheat from the world collection, German varieties were characterized by late ripeness, wheat from China, Japan, Bulgaria and the North Caucasus region of Russia by early ripeness and mid-ripeness, - varieties from the Siberian region of the country by mid-ripeness. Ukrainian cultivars were represented by wheat of different maturity groups. It has been found in the studies that under varying environmental conditions in different years early ripening, mid-early, mid-ripening and mid-late wheat can be highly productive. A well selected system of ripening varieties of soft winter wheat (65-70\% mid-ripening, $25 \%$ mid-early and early-ripening, 5-10\% mid-late) will make it possible to use favorable environmental factors with great efficiency and withstand environmental stresses.
\end{abstract}

\section{Introduction}

The duration of the growing season is an important characteristic of any crop variety. In wheat breeding, it is customary to make a judgement about the maturity group of a variety or breeding sample by the ear formation time.

The inter stage period of sprouting - ear development in comparison with the period of sprouting - ripening is less variable, which allows the ear development phase to be considered a reliable criterion for determining the ripeness group of wheat varieties [1].

Some studies have established a direct relationship between early maturity in the ear development phase and early maturity in the ripening phase [2, 3]. A positive close correlation between the time of the ear formation onset of soft winter wheat and the time of its ripening was also revealed in our experiments $-r=0.70 \pm 0.26$.

The issue of an association between productivity and the duration of the growing season in wheat is controversial. A general biological pattern is known: with an increase in the growing season, the duration of the photosynthetic apparatus of plants increases and, as a result, the yield of cultivated varieties increases. However, according to some researchers, the physiological incompatibility of early maturity and high yields is not absolute, and this negative correlation can be overcome by selection $[4,5]$.

It is also known that in the presence of environmental stress factors (drought, diseases, pests, etc.), early wheat varieties in some years can form higher yields than lateripening ones $[6,7]$.

The goal of the study was to establish a maturity group in varieties of soft winter wheat of various ecological and geographical origins in the forest-steppe of the Middle Volga region, as well as the dependence of yield on the time of ear development.

\section{Materials and methods}

Eighteen varieties of soft winter wheat included in the State Register of Breeding Achievements approved for use in the Middle Volga Region [8] served as the research material in mechanical sowing. Varieties were studied on plots of 4.5 $\mathrm{m}^{2}$ withfourfold replication.

The seeding rate is 5.5 million germinating seeds per 1 ha. In hand sowing on plots of $0.9 \mathrm{~m}^{2}$, without replication, 2 sets of soft winter wheat cultivars ( 51 pcs.) of various ecological and geographical origins were studied. The predecessor is bare fallow. Sowing was carried out in the time frame established for the studied crop- from August 25 to September 5.

The assessment of the phenological phases of growth and development of soft

* Corresponding author: nadejdazah@yandex.ru 
winter wheat and yield registration were carried out according to the methods recommended for the variety testing [9, 10]. The standard in the variety testing of soft winter wheat in the Ulyanovsk region during the years of research was the variety Volzhskaya $\mathrm{K}$.

\section{Results and Discussion}

According to the scale of the International Classifier ... (1984), different groups of wheat ripeness are distinguished: medium early, early, very early, medium late, late, very late -with ear development by $2-3,4-$ 5,6 or more days earlier or later than a mid-ripening standard variety. Wheat varieties that form the ear simultaneously with the standard variety or 1 day earlier or later are referred to the mid-ripening group [11]. In studies with mechanical sowing, $54 \%$ of soft winter wheat varieties proved to be mid-season, $24 \%$ - mid-early, $10 \%$ - mid-late (Table 1). Mid-ripening and mid-early groups of wheat were presented annually (78\% of the studied varieties). Late-ripe, early-ripe and ultra-ripe groups only in some years were represented by single varieties.

Earing was characterized by weak and medium variability. Inter-varietal coefficients of variation (Cv) varied from 4.9 to $11.9 \%$, and intra-varietal coefficients of variation ranged from 5.4 to $13.5 \%$ (Table 2). The highest inter-varietal coefficient of variation by the time of ear development was established in 2012 $11.9 \%$, when there was a differentiation in the resistance of soft winter wheat varieties to the Swedish fly (Oscinella frit L.) [7].

The variety Marafon was characterized by the earliest ear development in all years of the study- the average date for a 6-year research period is May 29. The genealogy of this variety has a well-known source of early ripeness - the Rusalka variety (Bulgaria) [8, 12].

The groups of mid-season, mid-late and late-ripening wheat varieties in different years of research included varieties Kazanskaya 285 and Moskovskaya 39, the ear development of which occurred 1-6 days later than the mid-season standard. The variability in terms of ear development periods of some wheat varieties with respect to other ones confirms the complex polygenic nature of the inheritance of the indicator of the growing season duration as a whole and its individual segments [1316].

Table 1. Distribution of winter wheat varieties between maturity groups (number/percent), mechanical sowing

\begin{tabular}{|c|c|c|c|c|c|c|}
\hline \multirow{2}{*}{ Years } & \multicolumn{7}{|c|}{ Maturity groups of wheat } \\
\cline { 2 - 7 } & $\begin{array}{c}\text { ultra- } \\
\text { ripe }\end{array}$ & $\begin{array}{c}\text { early- } \\
\text { ripe }\end{array}$ & $\begin{array}{c}\text { mid- } \\
\text { early }\end{array}$ & $\begin{array}{c}\text { mid- } \\
\text { ripe }\end{array}$ & mid-late & late-ripe \\
\hline 2011 & - & $1 / 7$ & $7 / 46$ & $6 / 40$ & - & $1 / 7$ \\
\hline 2012 & $2 / 13$ & $1 / 7$ & $3 / 20$ & $8 / 53$ & $1 / 7$ & - \\
\hline 2013 & - & - & $3 / 19$ & $9 / 56$ & $4 / 25$ & - \\
\hline 2014 & - & $3 / 19$ & $3 / 19$ & $7 / 44$ & $2 / 12$ & $1 / 6$ \\
\hline 2015 & - & $1 / 5$ & $4 / 23$ & $13 / 72$ & - & - \\
\hline 2016 & - & - & $3 / 17$ & $11 / 61$ & $3 / 17$ & $1 / 5$ \\
\hline Mean & $-/ 2$ & $1 / 7$ & $4 / 24$ & $9 / 54$ & $2 / 10$ & $-/ 3$ \\
\hline
\end{tabular}

Table 2. Ear development periods of soft winter wheat, mechanical sowing

\begin{tabular}{|c|c|c|c|c|c|c|c|c|}
\hline \multirow{2}{*}{ Variety } & \multicolumn{9}{|c|}{ Date of earing by the years } & \multicolumn{2}{c|}{$\mathrm{Cv}, \%$} \\
\cline { 2 - 8 } & 2011 & 2012 & 2013 & 2014 & 2015 & 2016 & mean & \\
\hline Volzhskaya K, standard & $6 \mathrm{VI}$ & $31 \mathrm{~V}$ & $2 \mathrm{VI}$ & $31 \mathrm{~V}$ & $5 \mathrm{VI}$ & $30 \mathrm{~V}$ & $3 \mathrm{VI}$ & 9.1 \\
\hline Volzhskaya 16 & $6 \mathrm{VI}$ & $1 \mathrm{VI}$ & $2 \mathrm{VI}$ & $31 \mathrm{~V}$ & $5 \mathrm{VI}$ & $31 \mathrm{~V}$ & $2 \mathrm{VI}$ & 7.7 \\
\hline Volzhskaya 100 & $3 \mathrm{VI}$ & $1 \mathrm{VI}$ & $31 \mathrm{~V}$ & $30 \mathrm{~V}$ & $4 \mathrm{VI}$ & $30 \mathrm{~V}$ & $2 \mathrm{VI}$ & 6.6 \\
\hline Volzhskaya C 3 & $4 \mathrm{VI}$ & $1 \mathrm{VI}$ & $1 \mathrm{VI}$ & $31 \mathrm{~V}$ & $5 \mathrm{VI}$ & $30 \mathrm{~V}$ & $2 \mathrm{VI}$ & 7.2 \\
\hline Bezenchukskaya 380 & $6 \mathrm{VI}$ & $2 \mathrm{VI}$ & $3 \mathrm{VI}$ & $2 \mathrm{VI}$ & $6 \mathrm{VI}$ & $2 \mathrm{VI}$ & $3 \mathrm{VI}$ & 5.7 \\
\hline Svetoch & $3 \mathrm{VI}$ & $26 \mathrm{~V}$ & $31 \mathrm{~V}$ & $28 \mathrm{~V}$ & $4 \mathrm{VI}$ & $1 \mathrm{VI}$ & $31 \mathrm{~V}$ & 11.2 \\
\hline Santa & $5 \mathrm{VI}$ & $1 \mathrm{VI}$ & $3 \mathrm{VI}$ & $30 \mathrm{~V}$ & $4 \mathrm{VI}$ & $30 \mathrm{~V}$ & $2 \mathrm{VI}$ & 7.8 \\
\hline Resurs & $4 \mathrm{VI}$ & $25 \mathrm{~V}$ & $1 \mathrm{VI}$ & $27 \mathrm{~V}$ & $2 \mathrm{VI}$ & $28 \mathrm{~V}$ & $30 \mathrm{~V}$ & 13.0 \\
\hline Kazanskaya 285 & $11 \mathrm{VI}$ & $1 \mathrm{VI}$ & $4 \mathrm{VI}$ & $2 \mathrm{VI}$ & $6 \mathrm{VI}$ & $3 \mathrm{VI}$ & $5 \mathrm{VI}$ & 10.2 \\
\hline Moskovskaya39 & $6 \mathrm{VI}$ & $1 \mathrm{VI}$ & $4 \mathrm{VI}$ & $4 \mathrm{VI}$ & $5 \mathrm{VI}$ & $2 \mathrm{VI}$ & $4 \mathrm{VI}$ & 5.4 \\
\hline Bazalt & $4 \mathrm{VI}$ & $29 \mathrm{~V}$ & $1 \mathrm{VI}$ & $28 \mathrm{~V}$ & $4 \mathrm{VI}$ & $29 \mathrm{~V}$ & $31 \mathrm{~V}$ & 10.0 \\
\hline Biryuza & $3 \mathrm{VI}$ & $28 \mathrm{~V}$ & $1 \mathrm{VI}$ & $26 \mathrm{~V}$ & $3 \mathrm{VI}$ & $28 \mathrm{~V}$ & $30 \mathrm{~V}$ & 11.4 \\
\hline Marafon & $2 \mathrm{VI}$ & $23 \mathrm{~V}$ & $30 \mathrm{~V}$ & $26 \mathrm{~V}$ & $1 \mathrm{VI}$ & $27 \mathrm{~V}$ & $29 \mathrm{~V}$ & 13.5 \\
\hline Kharkovskaya 92 & $3 \mathrm{VI}$ & $29 \mathrm{~V}$ & $2 \mathrm{VI}$ & $29 \mathrm{~V}$ & $3 \mathrm{VI}$ & $30 \mathrm{~V}$ & $1 \mathrm{VI}$ & 7.7 \\
\hline Mironovskaya 808 & $6 \mathrm{VI}$ & $1 \mathrm{VI}$ & $4 \mathrm{VI}$ & $30 \mathrm{~V}$ & $5 \mathrm{VI}$ & $30 \mathrm{~V}$ & $2 \mathrm{VI}$ & 9.2 \\
\hline Skipetr & - & - & $4 \mathrm{VI}$ & $1 \mathrm{VI}$ & $6 \mathrm{VI}$ & $31 \mathrm{~V}$ & $3 \mathrm{VI}$ & 8.2 \\
\hline Saratovskaya 17 & - & - & - & - & $5 \mathrm{VI}$ & $30 \mathrm{~V}$ & $2 \mathrm{VI}$ & 12.9 \\
\hline
\end{tabular}




\begin{tabular}{|c|c|c|c|c|c|c|c|c|}
\hline Novoershovskaya & - & - & - & - & $3 \mathrm{VI}$ & $30 \mathrm{~V}$ & $2 \mathrm{VI}$ & 12.9 \\
\hline Mean values in the experiment & $5 \mathrm{VI}$ & $30 \mathrm{~V}$ & $2 \mathrm{VI}$ & $30 \mathrm{~V}$ & $4 \mathrm{VI}$ & $30 \mathrm{~V}$ & $1 \mathrm{VI}$ & 9.4 \\
\hline From-to & $2 \mathrm{VI}-11 \mathrm{VI}$ & $23 \mathrm{~V}-2 \mathrm{VI}$ & $30 \mathrm{~V}-4 \mathrm{VI}$ & $26 \mathrm{~V}-4 \mathrm{VI}$ & $1 \mathrm{VI}-6 \mathrm{VI}$ & $27 \mathrm{~V}-3 \mathrm{VI}$ & $23 \mathrm{~V}-11 \mathrm{VI}$ & - \\
\hline Number of days & 10 & 11 & 6 & 10 & 6 & 8 & 8 & - \\
\hline Cv, $\%$ & 6.2 & 11.9 & 4.9 & 8.6 & 3.9 & 6.0 & 6.9 & - \\
\hline
\end{tabular}

In hand sowing, the earliest ear formation was recorded in 2012 - the average value in the experiment of May 29. In 2011 and 2013 it occurred on June 4. Vigorous ear development was recorded in 2013 - all samples formed the ear during 6 days (simultaneously with the standard variety or 2-3 days earlier or later) (table 3). In humid conditions of 2011, at low temperature, the ear formation lasted 16 days. In 2012, the ear formation of soft winter wheat was also prolonged (20 days, from May 22 to June 10), which was caused not only by genetic differences between crop varieties, but also by damage to the crops by the Swedish fly (Oscinella frit L.) [7].
Among the studied varieties of wheat of the world collection in the conditions of the forest-steppe of the Middle Volga region, German varieties were characterized by late ripeness that formed the ear later than the standard variety by 6-8 days. Ukrainian varieties were represented by wheat of different groups of maturity. Wheat varieties of China, Japan, Bulgaria and the Northern Caucasus region of Russia were characterized by early ripeness and mid-ripeness. Wheat of the Siberian region of the country formed the ear at the level of the mid-season standard (table 3).

Table 3. The date and period of earing of soft winter wheat varieties of various ecological and geographical origins, hand sowing

\begin{tabular}{|c|c|c|c|c|}
\hline \multirow{3}{*}{ Wheat origin } & \multicolumn{4}{|c|}{ Date and period of earing, from-to } \\
\hline & \multicolumn{2}{|c|}{ First set } & \multicolumn{2}{|c|}{ Second set } \\
\hline & 2011 & 2012 & 2012 & 2013 \\
\hline Volzhskaya K, standard & $5 \mathrm{VI}$ & $2 \mathrm{VI}$ & 2VI & 4VI \\
\hline Russia, Northern Caucasus & - & - & $25 \mathrm{~V}-3 \mathrm{VI}$ & 2VI-5VI \\
\hline Russia, Siberia & - & - & $30 \mathrm{~V}-3 \mathrm{VI}$ & 2VI-5VI \\
\hline Ukraine & $29 \mathrm{~V}-11 \mathrm{VI}$ & $23 \mathrm{~V}-3 \mathrm{VI}$ & $24 \mathrm{~V}-31 \mathrm{VI}$ & 2VI-6VI \\
\hline Germany & 12VI-13VI & 8VI-10VI & - & - \\
\hline Hungary & 2VI-6VI & $2 \mathrm{VI}$ & - & - \\
\hline Bulgaria & 1VI-4VI & $24 \mathrm{~V}-30 \mathrm{~V}$ & - & - \\
\hline Serbia & $6 \mathrm{VI}$ & $27 \mathrm{~V}-3 \mathrm{VI}$ & - & - \\
\hline China & 29V-7VI & $23 \mathrm{~V}-1 \mathrm{VI}$ & - & - \\
\hline USA & - & - & $22 \mathrm{~V}-2 \mathrm{VI}$ & 1VI-4VI \\
\hline Japan & - & - & $27 \mathrm{~V}-31 \mathrm{~V}$ & 1VI-5VI \\
\hline Estonia, Latvia & - & - & $26 \mathrm{~V}-4 \mathrm{VI}$ & 4VI-6VI \\
\hline Mean in the experiment & $4 \mathrm{VI}$ & $29 \mathrm{~V}$ & $29 \mathrm{~V}$ & $4 \mathrm{VI}$ \\
\hline $\mathrm{Cv}, \%$ & 8,9 & 13,4 & 12,9 & 4,3 \\
\hline From - to (number of days) & 29V-13VI (16) & $22 \mathrm{~V}-10 \mathrm{VI}(20)$ & $22 \mathrm{~V}-10 \mathrm{VI}(20)$ & 1VI-6VI (6) \\
\hline
\end{tabular}

a) the first set

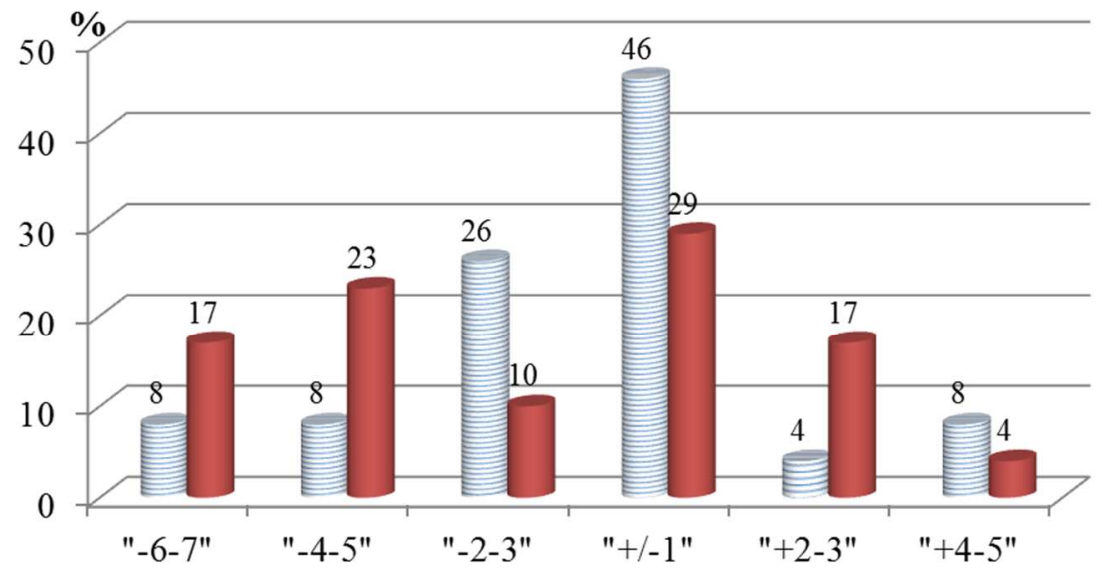

$\equiv 2011 \quad=2012$

Ear development period, $+/$ - days in relation to the standart

b) the second set 


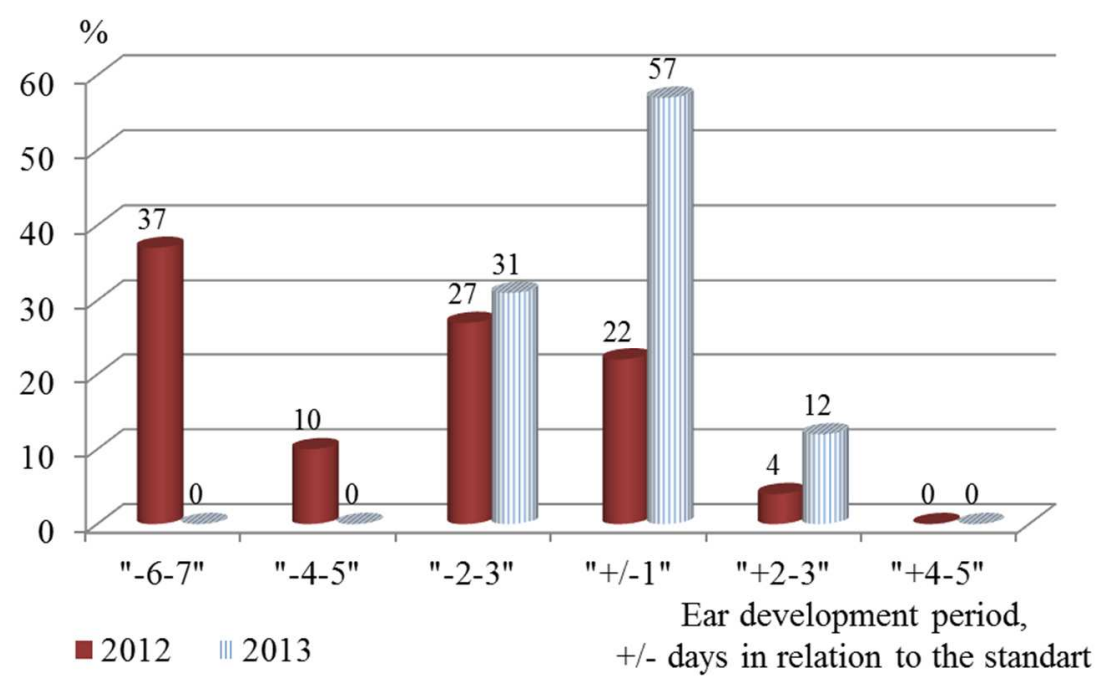

Fig. 1. The distribution of soft winter wheat varieties (\%) by maturity groups, hand sowing

In the first set of varieties of winter wheat in 2011 and 2012, which differ in moisture conditions in the spring-summer growing season (2011 - wet, 2012 - arid), the mid-ripening wheat group prevailed $46 \%$ and $29 \%$, respectively (fig. 1). Under conditions of moisture deficit in 2012, there was a general shift in the ear formation towards early ripeness. If in 2011 early ripe and ultra-ripe wheat amounted to $16 \%$ ( $8 \%$ each), then in 2012 it was $40 \%$ (17\% and $23 \%$, respectively). Late ripening wheat varieties in 2011 amounted to $8 \%$, in 2012 - $4 \%$. Intergenotypic coefficients of variation varied from $4.3 \%$ in 2013 to $13.4 \%$ in 2012, which, like in mechanical sowing, testifies to a weak and medium degree of variability of the indicator.

Victoria 95, Avesta (Russia), Vdachna, Shestopalivka, Myropol, Dukanka (Ukraine), Svilena, Emoile (Bulgaria), KS 8010-72, KS 96 WGRC 37, KS 96 WGRC 40,
Pacer (USA), Kitami 46 (Japan) and a number of samples from China were characterized by the early ear formation (by 2-11 days in comparison with the standard variety). The late-ripening group of wheat varieties comprised the German varieties Akter and Compliment, which form the ear 5-8 days later than the standard variety.

The graphs of regression analysis of yield from the date of ear development in hand sowing during the years of research had different directions (Fig. 2). In 2013, a reliable, inverse, medium-strength relationship was established between the analyzed indicators $(\mathrm{r}=-0.48$, the relationship was significant at the level of 1 $\%, \quad \mathrm{R}^{2}=0.2262$ ), which indicates the advantage of early ripening wheat. In 2012, in both sets, a positive relationship was observed between yield and the onset time of ear development of winter wheat. 


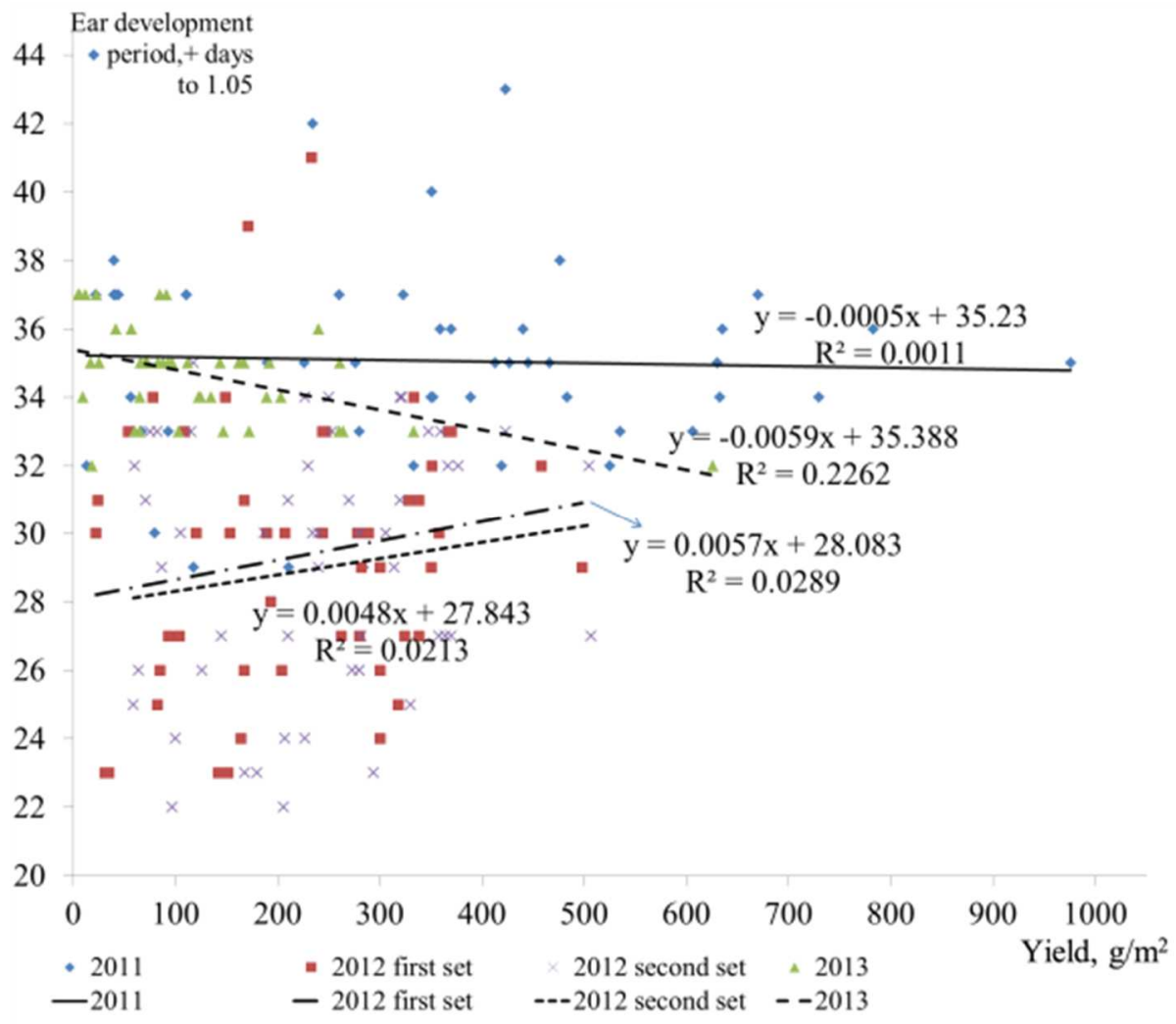

Fig. 2. The dependence of the yield of soft winter wheat from the date of ear development, hand sowing

Table 4. Yield $\left(\mathrm{g} / \mathrm{m}^{2}\right)$ of wheat varieties of different maturity groups, hand sowing

\begin{tabular}{|c|c|c|c|c|c|c|}
\hline Years & $\begin{array}{c}\text { "-"6-7 } \\
\text { days and } \\
\text { earlier }\end{array}$ & "-"-4-5 & "-"2-3 & $\begin{array}{c}\text { "+"/"-"1 } \\
\text { days } \\
\text { day in } \\
\text { relation to } \\
\text { the } \\
\text { standard } \\
\text { variety }\end{array}$ & $\begin{array}{c}\text { "+"2-3 } \\
\text { days }\end{array}$ & $\begin{array}{c}\text { "+"4-5 } \\
\text { days }\end{array}$ \\
\hline 2011 & 173 & 323 & 356 & 359 & 258 & 257 \\
\hline $\begin{array}{c}2012 \\
\text { (first set) }\end{array}$ & 207 & 300 & 169 & 258 & 230 & 174 \\
\hline $\begin{array}{c}2012(\text { sec } \\
\text { ond set) }\end{array}$ & 180 & 324 & 209 & 251 & 202 & - \\
\hline 2013 & - & - & 162 & 115 & 37 & - \\
\hline
\end{tabular}

When considering the yield by maturity groups of varieties, it can be stated that early ripening, mid-early and mid-ripening wheat can be highly productive in different years in the forest-steppe of the Middle Volga region. In the humid conditions of the spring-summer growing season of 2011, the average and middle-early wheat varieties had an advantage in yield - 359 and $356 \mathrm{~g} / \mathrm{m}^{2}$, respectively (table 4, Fig. 3).
In 2012 , early-ripening wheat varieties $\left(300 \mathrm{~g} / \mathrm{m}^{2}\right.$, first set and $324 \mathrm{~g} / \mathrm{m}^{2}$, second set) were the best in relation to yield, which quickly passed from the phenophases of tillering and shooting (damaged by the Swedish fly) to ear development. In the arid year of 2013, mid-early wheat varieties were the most productive $\left(162 \mathrm{~g} / \mathrm{m}^{2}\right)$.

The varieties Dashenka, Kalyanova, Lytavinka (Ukraine), Victoria 95, Donskaya Lira (Russia) were characterized by fast ripeness (the ear formation was by 2-8 days earlier than the standard variety) and yield at the standard level $(630,367$ and $162 \mathrm{~g} / \mathrm{m}^{2}$ in 2011, 2012 and 2013 respectively) or higher(table 5 ).

In the group of middle-ripening wheat varieties, the yield at the standard level of Volzhskaya $\mathrm{K}$ was formed by the variety Manzhelija (Ukraine) - in 2011, 2012 research years with 635 and $333 \mathrm{~g} / \mathrm{m}^{2}$, respectively. The wheat of the mid-late and late ripening groups was inferior in terms of yield to the standard. 


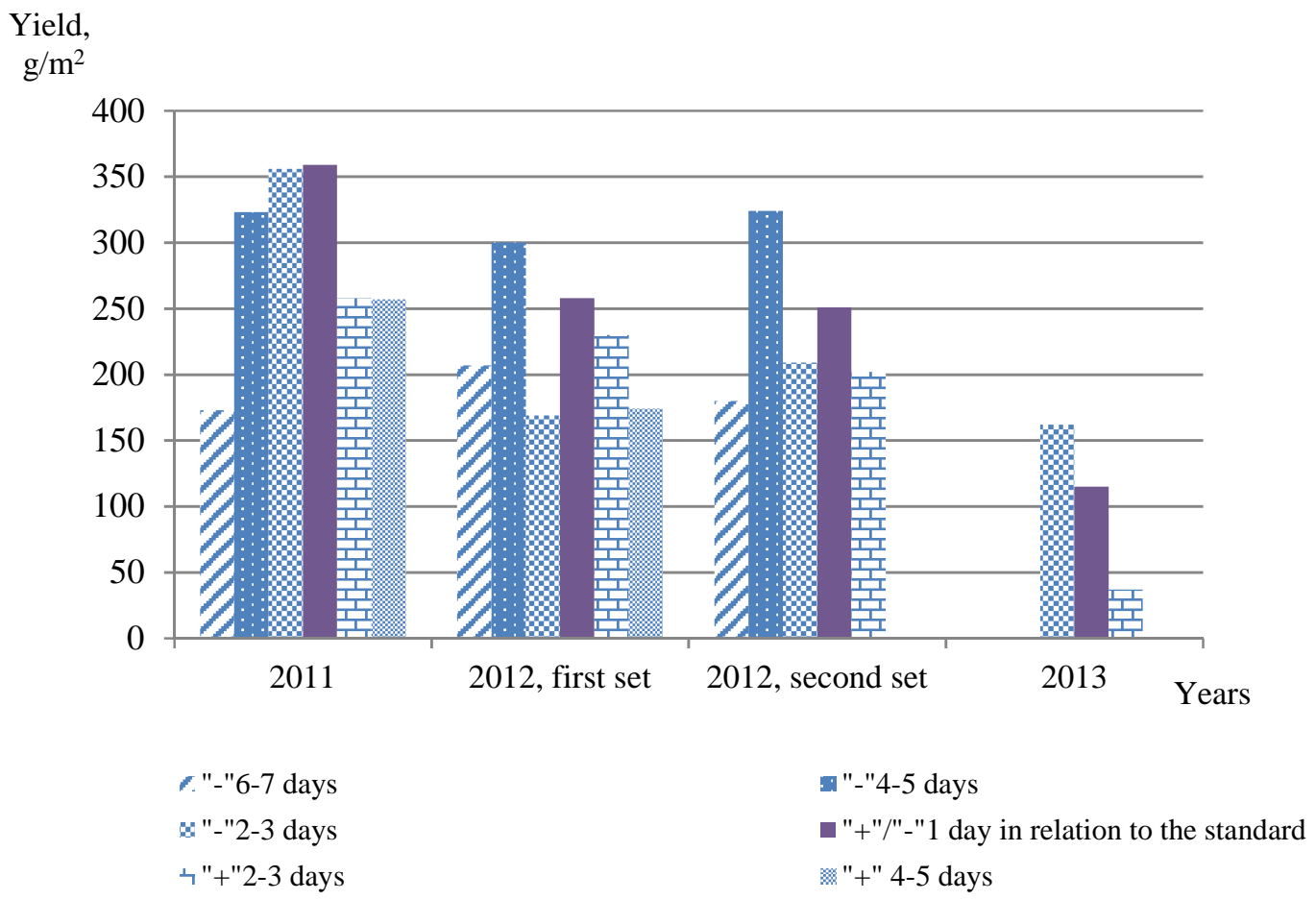

Fig. 3. Yield and early ripeness of soft winter wheat, hand sowing

Table 5. High productive, fast ripening varieties of soft winter wheat, hand sowing

\begin{tabular}{|c|c|c|c|c|c|c|}
\hline \multirow[t]{2}{*}{ Variety } & \multirow[t]{2}{*}{ Country } & \multicolumn{2}{|c|}{$\begin{array}{l}\text { Ear formation } \\
\text { «-» days in relation to } \\
\text { the standard }\end{array}$} & \multicolumn{3}{|c|}{$\begin{array}{l}\text { Yield, } \\
\mathrm{g} / \mathrm{m}^{2}\end{array}$} \\
\hline & & 2011 & 2012 & 2011 & 2012 & mean \\
\hline Volzhskaya $\mathbf{0}$, standard & & $5 \mathrm{VI}$ & $2 \mathrm{VI}$ & 630 & 367 & 498 \\
\hline Dashenka & $\begin{array}{l}\text { Ukrain } \\
\text { e }\end{array}$ & -2 & -6 & 730 & 338 & 534 \\
\hline Kalyanova & $\begin{array}{l}\text { Ukrain } \\
\text { e }\end{array}$ & -2 & -6 & 976 & 350 & 663 \\
\hline Lytavinka & $\begin{array}{l}\text { Ukrain } \\
\mathrm{e}\end{array}$ & -2 & -6 & 633 & 300 & 467 \\
\hline $\begin{array}{l}\text { Mean value in the } \\
\text { experiment }\end{array}$ & & $4 \mathrm{VI}$ & $29 \mathrm{~V}$ & $\begin{array}{c}328.8 \pm 32 \\
7\end{array}$ & $\begin{array}{c}218.1 \pm 16 \\
9\end{array}$ & $\begin{array}{c}273.5 \pm 20 . \\
7\end{array}$ \\
\hline & & 2012 & 2013 & 2012 & 2013 & mean \\
\hline Volzhskaya $\mathbf{0}$, standard & Russia & $2 \mathrm{VI}$ & $4 \mathrm{VI}$ & 367 & 162 & 265 \\
\hline Victoria 95 & Russia & -4 & -2 & 360 & 626 & 493 \\
\hline Donskaya lira & Russia & -8 & -2 & 330 & 172 & 251 \\
\hline $\begin{array}{l}\text { Mean value in the } \\
\text { experiment }\end{array}$ & & $29 \mathrm{~V}$ & $4 \mathrm{VI}$ & $\begin{array}{c}230.4 \pm 16 . \\
1\end{array}$ & $99.8 \pm 14.9$ & $\begin{array}{c}165.1 \pm 14 . \\
4\end{array}$ \\
\hline
\end{tabular}

Table 6. Yields of soft winter wheat varieties by maturity groups, mechanical sowing

\begin{tabular}{|l|c|c|c|c|c|c|}
\hline Group of wheat varieties & \multicolumn{7}{|c|}{ Yield, t/h0 } \\
\cline { 2 - 7 } & 2011 & 2012 & 2013 & 2014 & 2015 & 2016 \\
\hline $\begin{array}{l}\text { Mid-early and early-ripe } \\
\text { (fast ripening) }\end{array}$ & 3.46 & 1.63 & 2.51 & 3.96 & 2.36 & 5.59 \\
\hline Mid-ripe & 3.84 & 1.89 & 2.04 & 4.04 & 2.49 & 5.01 \\
\hline
\end{tabular}




\begin{tabular}{|l|c|c|c|c|c|c|}
\hline Mid-late & - & - & 2,58 & 3,82 & - & 3,33 \\
\hline Mean value in the & $3.64 \pm 0$. & $1.81 \pm 0$. & $2.26 \pm 0$. & $3.96 \pm 0$. & $2.46 \pm 0$. & $4.96 \pm 0$ \\
experiment & 18 & 10 & 12 & 19 & 10 & .15 \\
\hline
\end{tabular}

In mechanical sowing among the varieties of domestic selection in four years of research out of six (2011, 2012, 2014 and 2015), the mid-ripening group of wheat had an advantage in yield (table 6).

In 2013, yields of both the fast ripening group $(2.51 \mathrm{t} / \mathrm{ha})$ and the mid-late group $(2.58 \mathrm{t} / \mathrm{ha})$ exceeded that of the mid-ripening group (2.04 t/ha). In 2016 there was a strong lodging of soft winter wheat, which, as you know, is associated mainly with the height of plants. The fast ripening group of wheat $(5.59 \mathrm{t} / \mathrm{ha})$ was the most productive, compared with the mid-season one $(5.01 \mathrm{t} / \mathrm{ha})$ and medium-late $(3.33 \mathrm{t} / \mathrm{ha})$. Early ripening wheat varieties which include the varieties Biryuza and Marafon, have a plant height $(92-93 \mathrm{~cm})$ and average resistance to lodging (3.0 points), provided the highest yield $-5.59 \mathrm{t} / \mathrm{ha}$ in their group [17].

\section{Conclusion}

The conducted studies allow us to conclude that, in order to ensure the stability of wheat grain production in the forest steppe of the Middle Volga region, taking account of the annually changing weather conditions, it is expedient to grow varieties of different maturity groups in the ratio: $65-70 \%$ mid-ripening, $25 \%$ mid-early and early ripe, 5-10 \% mid-late. The most productive varieties Dashenka, Kalyanova, Lytavinka (Ukraine), Victoria 95, Donskaya Lira (Russia), and the midripening variety Manzhelija (Ukraine) can be recommended as a starting material in the selection of soft winter wheat for a combination of high productivity and early ripening. A correctly selected system of soft winter wheat varieties that ripen at different times will make it possible to use the most favorable environmental factors with maximum efficiency and withstand environmental stresses.

\section{References}

1. G.D. Nabokov, Inheritance of the duration of the growing season in soft winter wheat, Wheat and triticale, in: Mater. of the sci. Conf. "Green Revolution of P.P. Lukyanenko," pp. 480-488 (Krasnodar, 2001)

2. P.P. Lukyanenko, Selected Works (Kolos, Moscow, 1973), $448 \mathrm{p}$.

3. A.I. Nosatovsky, Wheat: Biology (Kolos, Moscow, 1965), $568 \mathrm{p}$.

4. N.V. Andriyash, A.I. Borodanenko, O.D. Gradchaninova, The sources of early ripeness for winter wheat selection, Transact. in Appl. Botany, Genet. and Select., 84, 23-28 (VIR, Leningrad, 1984)
5. K.V. Koleda, E.K. Zhivlyuk, I.I. Koleda, E.A. Borodich, The creation of breeding material for early-ripe soft winter wheat, Bull. of Belarus. State Agricult. Acad., 2, 45-49 (2012)

6. L.A. Bespalova, A.A. Romanenko, F.A. Kolesnikov, I.N. Kudryashov, I.B. Ablova et al., Wheat and triticale varieties of the Krasnodar Scientific Research Institute of Agriculture named after P.P. Lukyanenko (Krasnodar, 2015), 128 p.

7. N.N. Zakharova, N.G. Zakharov, Ecological adaptability of soft winter wheat varieties, Bull. of the Ulyanovsk State Agricult. Acad., 1(29), 15-21 (2015)

8. The state register of selection achievements. Retrieved from: http://reestr.gossortrf.ru/reestr/culture/1.html

9. State methods of crop variety testing; The second issue: grain crops, cereals, leguminous, corn and fodder crops (Moscow, 1989), $194 \mathrm{p}$.

10. Guidelines for the study of the world wheat collection, 3rd ed., revised (VIR, Leningrad, 1977), $27 \mathrm{p}$.

11. International Classifier CMEA of the genus Triticum (Leningrad, 1984), $50 \mathrm{p}$.

12. S.V. Rabinovich, N.N. Chetvertakova, Breeding and genetic potential of fast-ripening varieties of winter wheat, in: VI Congress of the Ukrainian Society of Genetics and Breeders named after N.I. Vavilov, vol. 2, pp. 28-29 (Poltava, 1992)

13. V.I. Fait, The study of the genetics of precocity per se in soft winter wheat, News of Zaporozhye State Univer., 1, 213-218 (2001)

14. E.K. Potokina, V.A. Koshkin, E.A. Alekseeva, I.I. Matvienko, V.A. Filobok, L.A. Bespalova, The combination of alleles of the Ppd and Vrn genes determines the time of heading in common wheat varieties, Vavilovsky J. of Genet. and Select., 16(1), 77-86 (2012)

15. G.A. Makarova; E.I. Ermakov, Physiological and genetic principles of earing period prediction and controlling recombinant wheat lines formation with given early ripeness, Doklady of Academy of Sciences, 326(1), 189-193 (1992)

16. Hiromi Matsuyama, Masaya Fujita, Masako Seki, Growth and yield properties of near-isogenic wheat lines carrying different photoperiodic response genes, Plant product. Sci., 18(1), 57-68 (2015)

17. N.N. Zakharova, N.G. Zakharov, M.N. Garanin, An association between the height of winter soft wheat plants and its yields and resistance to lodging in the forest-steppe of the Middle Volga, Bull. of the Ulyanovsk State Agricult. Acad., 1(49), 51-59 (2020) 